Vol. 16 (2007): 124-135

\title{
Genetic parameters for wool traits in Finnsheep lambs
}

\author{
Marja-Leena Puntila \\ MTT Agrifood Research Finland, Biotechnology and Food Research, FI-31600 Jokioinen, Finland \\ e-mail: marja-leena.puntila@surffinet \\ Katariina Mäki \\ Department of Animal Science, PO Box 28, FI-00014 University of Helsinki, Finland \\ Anne Nylander and Onerva Rintala \\ MTT Agrifood Research Finland, Biotechnology and Food Research, FI-31600 Jokioinen, Finland
}

\begin{abstract}
Genetic parameters were estimated for wool characteristics of white and coloured Finnsheep. The data consisted of 5309 lambs from ordinary production flocks, the Finnsheep nucleus flock and a breeding flock. The variance component estimation was done applying REML analyses. Wool traits included fleece uniformity, density, staple formation, lustre, crimp frequency, fineness grade and staple length. There was a smaller dataset that contained also lamb live weight, greasy fleece weight and additional fleece characteristics including fibre diameter measured with the OFDA method. The variance components for direct and maternal effects were estimated using bivariate analysis for 42-day, 120-day weight and greasy fleece weight. Heritability for visually assessed wool characteristics varied from 0.23 to 0.43 and for measured traits from 0.45 to 0.62 . Staple length had a high negative genetic correlation with crimp frequency and fineness grade. Heritability of greasy fleece weight was high $(0.55)$ and that of fibre diameter 0.62 . The genetic correlation between crimp frequency and fibre diameter was negative $(-0.56)$. The results imply that the assessed traits are useful indicators for fleece quality and those of major importance can be introduced into the breeding programme. The results suggest that there is no antagonism in selection for both growth capacity and wool quantity.
\end{abstract}

Key-words: fibres, Finnsheep, genetic parameters, live weight, OFDA, wool characteristics 
Vol. 16 (2007): 124-135

\section{Introduction}

The Finnsheep is widely known for outstanding fecundity and therefore the breed has been used in crosses and in developing synthetic multi-breed populations. Relatively little information is available on wool production and fleece characteristics of the breed, especially for lambs. In early Finnish studies Terho and Vainikainen (1938) reported the mean fibre diameter ranging from 22.6 to $39.7 \mu \mathrm{m}$ in adult Finnsheep with a considerable variation in fineness even within an animal. The same was observed later by Vainikainen and Hakola (1952) and Flanagan (1967). The wool varies in type, from long coarse hairs to finer bottom wool (Vainikainen, 1946). According to Terho and Vainikainen (1938), the level of medullation is low (4.5\%) in ewe wool at autumn shearing. Similarly Flanagan (1967) found that medullated fibres are rare in Finnsheep fleeces. Scottish experts assessed the Finnsheep wool semilustrous and free of kemp and very soft and silky to handle and being usually of medium fineness (Donald and Read 1967). However, in wool quantity Finnsheep cannot compete with other breeds.

Sheep farmers have not received any subsidy for wool since 1995 when Finland joined the European Union. Now the wool prices are ruled by the small spinning mills, and the prices have been generally low. When EU subsidies were introduced for raising endangered colour types of Finnsheep, the numbers of black, brown and grey type sheep increased considerably, also partly as a response to consumer demand for "natural wool." Selection schemes for different use of Finnsheep were started in 1986 at the state-owned farm of Pelso. More information about the selection objectives at this nucleus flock, has been given by Puntila et al. (1990) and Puntila \& Nylander (1997).

This paper presents results based on the data of the nucleus flock and of the ordinary production flocks in the Fine Finnwool project (EU $5 \mathrm{~b}$ framework programme for regional development). The project was established to stimulate the drastically declined wool production and the improvement schemes for wool quality. Some of the work was carried out in the contemporary European Fine Fibre Network (EFFN). The network had a goal to develop European standards for the objective measurement used in selection for quantity and quality of fibre traits (Laker 1999).

The current work was aiming at establishing the breeding objectives and selection criteria for wool traits in Finnsheep lambs: The first objective was to collect data on wool characteristics by subjective assessment and measurement procedures and to use the data to estimate heritabilities and genetic correlations for the wool traits. The second objective was to study how lamb growth and fleece weight are correlated. The study was carried out in lambs, because information on adult sheep would be more difficult to obtain in practise. Information on young animals would speed up the selection. The inclusion of wool traits completes the current selection profile which is focussed on meat production traits.

\section{Materials and methods}

\section{Data and animals}

The data came from different sources and there were two datasets as presented in Table 1. Data I consisted of the records for wool traits of spring-born lambs from 17 flocks of the Fine Finnwool-project in 1997-99. It included both white and coloured Finnsheep. Most of these flocks in southwestern Finland were small (medium size 26 ewes/flock) and were classified as handicraft flocks with increasing interest in coloured Finnsheep. Pedigree information included at least four generations which provided links between animals through grandsires and great grandsires. In order to have more data for both, white and coloured Finnsheep and to provide more genetic links for estimation of variance components, the data was augmented by records from animals born between 1993 and 1999 (except 1997) in the Finnsheep nucleus flock on a state-owned farm Pelso and from animals born in 1997-1998 in a private breeding flock with 
Puntila, M.-L. et al. Genetic parameters for wool traits in finnsheep lambs

Table 1. Structure of datasets, traits analysed and number of animals.

\begin{tabular}{|c|c|c|}
\hline & Data I & Data II \\
\hline Total animals & 5309 & 2129 \\
\hline Sires & 102 & 44 \\
\hline Dams & 876 & 492 \\
\hline $\begin{array}{l}\text { Total no.animals with } \\
\text { records }\end{array}$ & 2995 & 1786 \\
\hline Proportion of females & 0.53 & 0.54 \\
\hline Mean (SD) of days & $155(27.9)^{\mathrm{a}}$ & $181(30.8)^{b}$ \\
\hline \multicolumn{3}{|c|}{ Recorded animals per trait } \\
\hline Fleece uniformity & 2904 & \\
\hline Density & 2995 & \\
\hline Staple formation & 2903 & \\
\hline Lustre & 2994 & \\
\hline Crimp freguency & 2903 & \\
\hline Fineness grade & 2995 & \\
\hline Staple length & 2994 & \\
\hline Fibre diameter & 448 & \\
\hline Greasy fleece weight & 523 & 1786 \\
\hline Live weight & 1408 & \\
\hline 42-day weight & & 1786 \\
\hline 120-day weight & & 1771 \\
\hline \multicolumn{3}{|c|}{${ }^{\mathrm{a}}$ age at assessment (standard deviation SD in brackets) } \\
\hline \multicolumn{3}{|l|}{${ }^{\mathrm{b}}$ age at shearing } \\
\hline \multicolumn{3}{|c|}{ Data I: white and coloured lambs } \\
\hline \multicolumn{3}{|l|}{ Data II: white lambs } \\
\hline
\end{tabular}

white Finnsheep. The Pelso data included also records from coloured lambs born in 1998-1999. The colour types are descending from a common ancestral base and have been separated from each other within the last few generations. The data had progeny of altogether 102 sires - with $13.1-19.2$ recorded progeny per sire - and of 876 dams. Data II was based on the records of growth and fleece weight in white lambs at the Finnsheep nucleus flock born between 1986 and 1998 as progeny of 44 sires and 492 dams.

\section{Traits recorded}

The following wool characteristics (with respective scoring) were assessed and included in the analyses:

- Score for fleece uniformity (FU): Uniformity of fleece describes the overall impression of the wool quality over the body. The main attention in this score is paid to uniformity in staple length and size of curl. Uniformity is given points between 1 and 5 with 1 representing a high deviation between shoulder and britch area and 5 being the most desirable value. Fleece uniformity is important for wool processing.

- Score for density (DS): Density generally means the number of fibres per unit area of the skin. How well the fleece covers the skin and how thick it is, can be learned by handling and tactile feeling of fleece thickness. Density is given points between 1 and 5 with 1 and 2 representing a low covering and 5 a very thick fleece, often with too short a staple length. A thickness score 4 is the most preferable one.

- Score for staple formation (SF): Uniformity within staples has scores between 1 and 5 with 1 corresponding to straight fibre with no staples and 5 to overall firm wool with tapering and clear staples.

- Score for lustre (LS): Lustre is given points between 1 and 5 with score 1 wool being matt and $\operatorname{dim}$ and the score 5 wool being highly lustrous, silky and shiny.

- Crimp frequency (CF): Crimp frequency is based on the number of crimps per $3 \mathrm{~cm}$ and measured by a ruler on the butt portion of staples.

- Fineness grade (FG): Fineness is classified by grades from 46 to 60 and assessed subjectively on shoulder, midside and britch $\mathrm{f}$ the body and based mainly on the size of curl. A fineness grade corresponding to 54 (medium size of curl) is the most preferable one.

- Staple length (SL): Staple length (nonstreched) is measured by a ruler on three locations: shoulder, midside and britch. The average of the three measurements is used in the analysis.

Grading of wool quality in the flocks of the Fine Finnwool project was carried out by a trained team and in the nucleus flock by an experienced assessor. The grading was done for lambs at about five to six months of age. Individual fleece weights 
Vol. 16 (2007): 124-135

were recorded at shearing and live weights were measured at scoring the wool quality traits. Because greasy fleece weights (GFW) and live weights (LW) were available mainly at the nucleus flock, there are less observations for these traits than for wool quality traits. Wool samples were collected yearly from lambs born in the recorded flocks, the aim was to form large half-sibs groups for estimation variance components and therefore to record mainly progeny of the same sires in different years. The wool samples were taken from the mid-side of animals according to the guidelines for sample collection by the European Fine Fibre Network (Souchet 1997). The samples were sent to the Macaulay Land Use Research Institute (UK) where fibre diameter was determined by the OFDA method (Optical Fibre Diameter Analyser). The OFDA instrument is based on automatic image analysis technology. It is pooling the rapidly and accurately taken measurements into mean diameter (MFD), standard deviation (SD) and coefficient of variation (FDcv) (Qi et al.1994).

\section{Statistical analyses}

Preliminary analyses of the data for fixed effects and covariables were carried out using GLM procedures (SAS, Inc., 1999-2000). The fixed effects for all the traits were sex $(\mathrm{k}=1,2)$, birth/rearing type $(1=1$ to 7$)$, flock-year $(i=1-54)$, colour (white, black, brown, grey, $j=1$ to 4 ) and age at assessment as a covariate ( $b$ as the respective regression coefficient). Age of dam (1 to 7 years) was not found to have a significant effect on most of the traits and was omitted in the variance component analysis. Therefore the basic statistical model in the variance component estimation was

trait value $=\mu+$ flock-year $_{i}+$ colour $_{j}+$ sex $_{k}+$ birth rearing type ${ }_{1}+\mathrm{bx}$ age at assessment + animal $_{\mathrm{m}}+$ residual $_{\mathrm{ijklm}}$

where animal and residual are random effects. The model was adjusted to different options in the analyses. Dataset I was analysed for several wool traits using multi-trait REML analyses with VCE4 software (Neumaier and Groeneveld, 1998). The statistical model had the fixed effects flock $\mathrm{x}$ year and colour type and age at assessment as a covariate. Animal and residual effects were assumed to be random with zero mean and var $=\mathbf{A} \otimes \mathbf{G}_{\mathbf{0}}$ and var $=\mathbf{I} \otimes \mathbf{R}_{\mathbf{0}}$, respectively, where $\mathbf{A}$ is the additive genetic relationship matrix between the animals, $\mathbf{G}_{\mathbf{0}}$ and $\mathbf{R}_{\mathbf{0}}$ are 4 by 4 (co)variance matrices of animal and residual effect, respectively, and $\otimes$ denotes the direct product operator.

From Data I (co)variance components were estimated for LW, GFW, CF, SL, MFD and $\mathrm{FD}_{\mathrm{cv}}$ in six-trait analysis to get the relationships between growth rate, fleece weight and wool quality traits.

A further analysis including maternal effects and estimation of covariance components was carried out between 42W, $120 \mathrm{~W}$ and GFW from Data II using an AI-REML procedure with the DMU package program (Jensen \& Madsen 1994). The random effects were animal, maternal, common environment (due to litter) and residual effect. The phenotypic variance was computed as the sum of the estimated variance components including the impact of covariation between the random effects. The fixed parts of the model included effects of birth/rearing type, sex, age of dam, selection line (meat, wool, pelt) and year (there was only one flock, i.e. the nucleus flock). The shearing age was used as a covariate for fleece weight. Heritabilities for direct effects $\left(\mathrm{h}^{2}{ }_{\mathrm{d}}\right)$ and for maternal effects $\left(\mathrm{h}^{2}{ }_{\mathrm{m}}\right)$ were calculated from the estimated (co)variance components.

\section{Results and discussion}

\section{Means and variation}

Means and coefficients of variation for wool traits are presented for different colours of Finnsheep lambs in Table 2. White lambs had higher scores than the coloured ones in FU, SF and LU. All colour types seemed to be alike for CF except the black ones which had less crimps per unit length. The crimp 
Puntila, M.-L. et al. Genetic parameters for wool traits in finnsheep lambs

Table 2. Means and coefficients of variation (CV) for wool quality traits in white and coloured Finnsheep lambs (Data I).

\begin{tabular}{|c|c|c|c|c|c|c|c|c|}
\hline \multirow[t]{2}{*}{ Colour type } & \multicolumn{2}{|c|}{ White } & \multicolumn{2}{|c|}{ Black } & \multicolumn{2}{|c|}{ Brown } & \multicolumn{2}{|c|}{ Grey } \\
\hline & mean & $\mathrm{CV}$ & mean & $\mathrm{CV}$ & mean & $\mathrm{CV}$ & mean & $\mathrm{CV}$ \\
\hline No of observations & 1583 & & 586 & & 721 & & 52 & \\
\hline Fleece uniformity & 3.44 & 24.04 & 2.91 & 30.46 & 3.11 & 26.92 & 3.17 & 23.62 \\
\hline Density & 3.11 & 22.90 & 3.53 & 18.35 & 3.37 & 18.40 & 3.63 & 22.01 \\
\hline Staple formation & 3.01 & 28.08 & 2.24 & 38.82 & 2.42 & 35.44 & 2.48 & 33.98 \\
\hline Lustre & 3.41 & 20.47 & 2.89 & 25.19 & 2.80 & 25.63 & 3.23 & 23.33 \\
\hline Crimp frequency & 6.55 & 26.92 & 5.61 & 35.89 & 6.45 & 30.63 & 6.25 & 29.70 \\
\hline \multicolumn{9}{|l|}{ Fineness grade } \\
\hline front & 54.07 & 2.13 & 53.65 & 2.48 & 54.22 & 2.24 & 54.16 & 2.90 \\
\hline midside & 53.69 & 2.59 & 52.95 & 3.32 & 53.70 & 2.97 & 53.52 & 2.98 \\
\hline britch & 53.49 & 2.49 & 52.58 & 3.71 & 53.43 & 3.04 & 53.44 & 3.54 \\
\hline Staple length, cm & 7.16 & 28.02 & 7.74 & 27.31 & 6.30 & 27.46 & 7.51 & 25.38 \\
\hline Fibre diameter, $\mu \mathrm{m}$ & 24.79 & 9.90 & 25.93 & 8.04 & 25.43 & 8.64 & 25.12 & 7.37 \\
\hline Age at assessment, $\mathrm{d}$ & 155.61 & 21.08 & 152.53 & 14.12 & 154.62 & 13.41 & 150.19 & 10.32 \\
\hline
\end{tabular}

Fleece uniformity, density, staple formation and lustre assessed according to a score 1-5 (5 = max), crimp frequency ( number of crimps per $3 \mathrm{~cm}$ ), fineness grade 46-60 (60 finest).

Number of sampled animals for fibre diameter: white 276, black 65, brown 113, grey 16.

was not always well developed or visible, because substantial proportion of crimps appeared "fuzzy", especially in coloured fleeces. This made it difficult to measure crimp numbers. We found that $20 \%$ of the variation in the crimp frequency was associated with the variation in fibre thickness. According to Puntila (2002) crimp frequency per fibre length can be used as a rough estimate for fibre thickness, as thinner fibres tend to have more crimps.

The denser fleece was clearly more typical to the coloured Finnsheep. Brown staples were shorter than those in the other colour types.

Lustre is a well-recognized characteristic in Finnsheep wool. In an early study Terho and Vainikainen (1938) showed that the scale pattern of fibre cuticle is irregularly polygonal in Finnsheep and that the cuticle scales form only one layer with parallel alignment, resulting in strong and uniform lustre. The frequency distribution (not shown) indicates that $5 \%$ of white Finnsheep had high lustre and silky wool. Dust, dirt and light circumstances influence the visual assessment of lustre.

A mean fibre diameter measured by OFDA was 24.8 and $25.6 \mu \mathrm{m}$ for white and coloured Finnsheep lambs, respectively. The sire group with the finest
FD had a fibre diameter of $21.4 \mu \mathrm{m}$ for ram lambs $(\mathrm{n}=12)$ and $22.8 \mu \mathrm{m}$ for ewe lambs $(\mathrm{n}=9)$. The mean fibre diameter in older rams $(\mathrm{n}=11)$ varied from 28.4 to $37.6 \mu \mathrm{m}$ and SD from 5.0 to $10.1 \mu \mathrm{m}$. Previous studies based on airflow measurements gave FD of $23.4 \mu \mathrm{m}$ (SD 1.74) for lambs and 29.3 $\mu \mathrm{m}$ (SD 1.93) for ewes in the wool line of the nucleus flock (Puntila and Nylander 1996). Fahmy (1987) showed that the fibre thickness decreases with $0.48 \mu \mathrm{m}$ for each $1 / 8$ increase of Finnsheep in different cross combinations between Finnsheep and British breeds. The mean $\mathrm{FD}_{\mathrm{cv}}$ was $22.5 \%$ in white Finnsheep lambs, ranging from 16 to $41 \%$. The frequency of medullation was measured only for white fleeces. Kemp fibres were rare. There were around twenty samples where the proportion of undesirable fibres exceeded $1 \%$, generally this was less than $0.1 \%$.

Figure 1 presents an example on the OFDA histogram printout for a wool sample, showing the mean fibre diameter, SD, CV and sample size of fibre snippets. The histogram example represents a typical fibre thickness in white Finnsheep lambs. The OFDA measures also the distribution of fibre opacity and the printout gives specific medullation 
Fig.1. The OFDA histogram showing the fibre diameter distribution in a typical sample of wool from a white Finnsheep lamb. See the text for explanations.

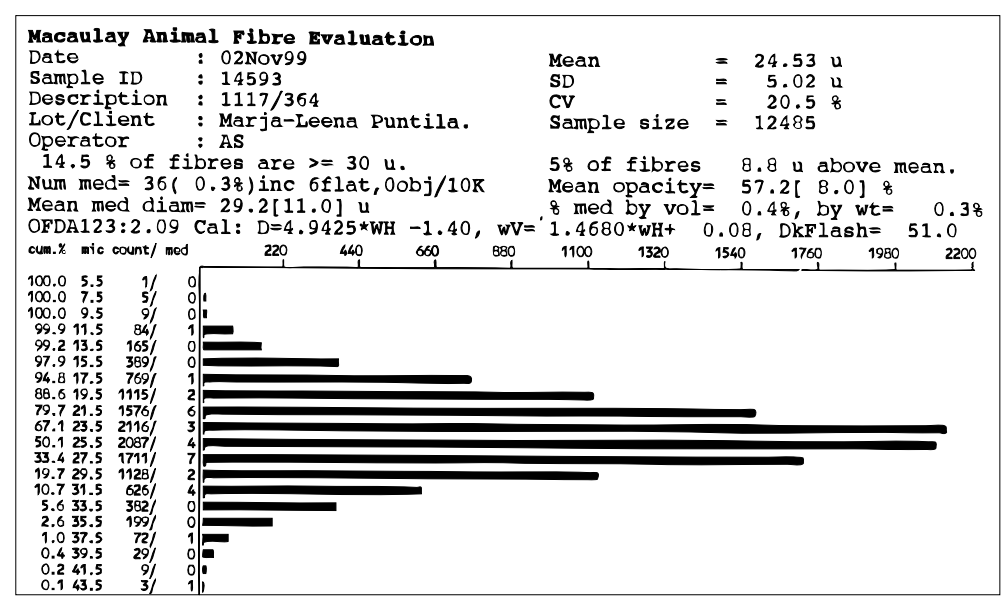

results (Lupton and Pfeiffer, 1998).

The average fleece weight of lambs in this study was $1.1 \mathrm{~kg}$ (not shown). Puntila \& Nylander (1997) reported the fleece weight of Finnsheep lambs 1.3 $\mathrm{kg}$ in the wool line at the Finnsheep nucleus flock (in adult ewes it was $3.1 \mathrm{~kg}$ ).

\section{Fixed effects}

Summary of the significance of the main effects on wool traits are shown in Table 3. Sex had a significant effect on all the traits except FU and SF. Ewe lambs had slightly higher DS and LU and also their fleece was longer, whereas the male lambs had higher CF, FG and a smaller FD $(24.6 \mu \mathrm{m}$ vs $25.6 \mu \mathrm{m})$. Gjedrem (1969) found the male lambs to have finer wool but in adult sheep the difference between sexes was reversed. Ryder and Wilson (1972) found also coarser fibres in the females in Finnsheep x Merino crosses. Sumner and Bigham (1993) reported slightly greater FD in rams with the difference between the sexes increasing with age.

In the present study the single born and reared lambs had slightly better FU and SF and higher $\mathrm{CF}$ than those born and reared as quadruplet or quintuplet. There was no significant difference in FD between the birth/rearing types, which is given a support by the Norwegian study (Gjedrem 1969).
The birth /rearing type $=7$ corresponding to artificially reared lambs had poorer scores for almost all subjectively assessed traits, shorter staples and somewhat lower CF than in their contemporaries reared by the mothers.

Age had a very high effect on SL. The most prominent difference was between lambs sampled at the age between 80 and 139 days and lambs sampled when over 200 days old. The mean SL in this early group was $11 \mathrm{~cm}$ compared to $7.5 \mathrm{~cm}$ in the later group. The CF and DS score were lower in the younger age group.

Table 3. Summary of significance values for the classified effects (sex, birth/rearing type and colour and covariate (age) included in the analysis of variance (Data I).

\begin{tabular}{|c|c|c|c|c|}
\hline Trait & Sex & $\begin{array}{l}\text { Birth/ } \\
\text { rearing } \\
\text { type }\end{array}$ & $\begin{array}{c}\text { Age at } \\
\text { assessment }\end{array}$ & Colour \\
\hline $\begin{array}{l}\text { Fleece } \\
\text { uniformity }\end{array}$ & ns & 0.001 & ns & 0.001 \\
\hline Density & 0.001 & 0.001 & 0.001 & 0.001 \\
\hline Staple formation & ns & 0.001 & 0.05 & 0.001 \\
\hline Lustre & 0.001 & 0.01 & 0.01 & 0.001 \\
\hline $\begin{array}{l}\text { Crimp } \\
\text { frequency }\end{array}$ & 0.001 & 0.05 & 0.05 & 0.001 \\
\hline Fineness grade ${ }^{a}$ & 0.001 & 0.05 & ns & 0.001 \\
\hline Staple length & 0.001 & 0.01 & 0.001 & 0.001 \\
\hline
\end{tabular}

${ }^{a}$ midside 
Puntila, M.-L. et al. Genetic parameters for wool traits in finnsheep lambs

Table 4. Estimates of heritability (on diagonal) and genetic correlations (above diagonal) with standard errors (in brackets) and phenotypic correlations (below diagonal) for wool quality traits in Finnsheep lambs (Data I).

\begin{tabular}{lccccccc}
\hline Trait & FU & DS & SF & LU & CF & FG & \multicolumn{1}{c}{ SL } \\
\hline Fleece uniformity (FU) & $\mathbf{0 . 2 8}(\mathbf{0 . 0 2})$ & $0.20(0.05)$ & $0.64(0.03)$ & $0.27(0.05)$ & $0.32(0.07)$ & $0.31(0.07)$ & $-0.26(0.06)$ \\
Density (DS) & 0.10 & $\mathbf{0 . 3 8}(\mathbf{0 . 0 3})$ & $0.10(0.04)$ & $-0.16(0.04)$ & $0.43(0.04)$ & $0.44(0.04)$ & $-0.34(0.04)$ \\
Staple formation (SF) & 0.36 & -0.13 & $\mathbf{0 . 3 2 ( 0 . 0 2 )}$ & $0.69(0.04)$ & $0.23(0.04)$ & $0.26(0.04)$ & $-0.10(0.05)$ \\
Lustre (LU) & 0.16 & 0.02 & 0.35 & $\mathbf{0 . 2 3 ( 0 . 0 2 )}$ & $-0.30(0.04)$ & $-0.32(0.04)$ & $0.49(0.04)$ \\
Crimp frequency (CF) & 0.20 & 0.19 & 0.08 & -0.15 & $\mathbf{0 . 4 5 ( 0 . 0 3 )}$ & $0.99(0.00)$ & $-0.85(0.02)$ \\
Fineness grade (FG) & 0.20 & 0.23 & 0.09 & -0.14 & 0.87 & $\mathbf{0 . 4 3 ( 0 . 0 3 )}$ & $-0.88(0.01)$ \\
Staple length (SL) & -0.14 & -0.08 & -0.05 & 0.25 & -0.53 & -0.53 & $\mathbf{0 . 6 2 ( 0 . 0 2 )}$ \\
\hline
\end{tabular}

\section{Heritability estimates}

Estimates of heritability, genetic and phenotypic correlations for wool traits are presented for Data I in Table 4 . The $\mathrm{h}^{2}$ for subjectively assessed wool traits were in the range from 0.23 to 0.38 , which is in close agreement with studies on South Australian Merino hoggets (James et al. 1990), on Icelandic lambs (Eythorsdottir 1999) and on pelt quality traits for Gotland lambs (Näsholm 2005). The $\mathrm{h}^{2}$ was high for crimp frequency $(0.45)$ and fineness quality grade (0.43), both characterizing fineness. The high $\mathrm{h}^{2}$ of crimp frequency has also been found by Wuliji et al. (2001) in ultrafine Merinos at 10 months of age. Most of the heritability estimates for wool traits are reported for yearlings or adult ewes. CF has been found to have heritability estimates over a broad range stretching from 0.24 to 0.78 (Gregory 1982, Safari et al. 2005).

The $\mathrm{h}^{2}$ of SL in the present study is higher (0.62) than has been found in Norwegian Dala and Steigar lambs (0.44) (Gjedrem, 1969) and in the Scottish Blackface (0.52) lambs (Conington and Murphy 2003). Wuliji et al. (2001) have found a heritability of 0.71 in the Merinos, which was higher than the reviewed weighted value 0.46 reported by Safari et al. (2005).

Genetic parameters for LW, GFW and measured wool traits in lambs are shown in Table 5. The $h^{2}$ of $0.44 \pm 0.04( \pm$ SE) for LW was much higher than the estimates for weaning weights summarized by Fogarty (1995) and Safari et al. (2005) for dual-purpose breeds and also those given by Hanford et al. (2005) for Rambouillet sheep. The $\mathrm{h}^{2}$ of $0.55 \pm 0.07$ for GFW was high and also somewhat higher than previously found $(0.41 \pm 0.06)$ for Finnsheep lambs (Puntila and Nylander 1997). The reviewed estimates by Fogarty (1995) and Safari et al. (2005) for dual purpose breeds are 0.36 and 0.38 , respectively. Conington and Murphy (2003) found a high heritability (0.46) for GFW at 14 months of age, being in line with the results by Atkins (1986), both estimated in the Scottish Blackface sheep. Wuliji et al. (2001) have found values that are in the lower range of the ones above and of the previous estimates for the Merinos (James et al. 1990).

There are few estimates of genetic parameters for lamb fleece weight. Young et al (1965) found $h^{2}$ estimates for this trait being between 0.2 and 0.3 in the age interval from 5 to 12 months. Later Olesen (1995) has reported a figure 0.24 , on the other hand Yazdi et al. (1997) have found no significant heritability for the Baluchi lambs

FD is considered to be a highly heritable trait. The $h^{2}$ of MFD (0.62) in the present study is consistent with the estimates of 0.52 and 0.57 for dual-purpose breeds given by Fogarty (1995) and Safari et al. (2005), respectively. Wuliji et al. (2001) have estimated $\mathrm{h}^{2}$ for the fibre diameter measured at the age of 16 months to be very similar to that measured at 10 months of age $(0.55$ and 0.58 , respectively) for the Merinos.

The $\mathrm{h}^{2}$ of $\mathrm{FD}_{\mathrm{cv}}$ found here $(0.54)$ is close to the estimates given by Safari et al. (2005). Coefficient of variation in fibre diameter plays a role in processing and in deciding about the end products (Wuliji et al. 1999). Wuliji et al. (2001) discussed 
Vol. 16 (2007): 124-135

whether $\mathrm{FD}_{\mathrm{cv}}$ should be included in the selection objectives for fine wool as the prickle factor of fabric is corresponding to fibres coarser than $30 \mu \mathrm{m}$.

\section{Relationship between wool traits}

Crimp frequency and fineness grade were genetically highly correlated (Table 4 ). This shows that measured crimp number per $3 \mathrm{~cm}$ is a good indicator for wool fineness. The moderate genetic correlation of these two traits (CF and FG) was positive with DS and high and negative with SL (-0.85). High CF combined with low SL would most likely result in a reduction of greasy wool weight (GFW). New findings (Bray et al. 2002) based on bimodality of distribution of $\mathrm{FD}_{\mathrm{cv}}, \mathrm{CF}$ and SL in crossbred Finnsheep would suggest the genetic variation to be due to genes with major effect on the wool traits. We may speculate that the high heritabilities and genetic correlations could be explained by the segregation of major genes in the Finnsheep.

Fleeces with high SF are probably more uniform over the body. The desirable LU in Finnsheep can be genetically improved by increasing SF and keeping crimp number at 6 to 8 per $3 \mathrm{~cm}$. Genetic and phenotypic correlations for these traits had a similar sign, while the genetic correlations were larger in absolute magnitude than the phenotypic correlations.

There was a high genetic correlation between LW and GFW (0.56) in the present study. (Table 5). The estimate is higher than those in the reviews by Fogarty (1995) and Safari et al. (2005) for live weights at various ages. Very low genetic relationship in lambs $(0.10)$ has been reported by Olesen et al. (1995).

The genetic correlation was positive between GFW and SL (0.35), and negative between GFW and CF (-0.14). In our previous larger study (Puntila and Nylander 1997), we found the genetic correlation to be 0.59 between GFW and SL. These estimates suggest that selection for high wool weight is likely to give positive response for staple length. Similar results have been found for the correlation between GFW and SL or FG, and between SL and FG in Columbia, Targhee and Rambouillet adult sheep (Hanford et al. 2002, 2003 and 2005).

In our study GFW had high positive genetic correlation with FD (0.69). This is consistent with the estimate by Notter and Hough for the Targhee sheep (1997). In the review by Safari et al. (2005) the mean genetic correlation between GFW and FD was 0.36 and slightly lower in the recent study by Safari et al. (2007) on Merino sheep.

In our study on Finnsheep the genetic correlation between $\mathrm{CF}$ and FD was negative and high (- 0.56). In the Merinos, the genetic correlations were also negative, but much closer to zero (Wuliji et al. 1999 and 2001).

\section{Maternal effects}

Direct and maternal heritability for GFW and 120W weight were similar, $\mathrm{h}_{\mathrm{d}}=0.36$ and $0.38, \mathrm{~h}_{\mathrm{m}}{ }_{\mathrm{m}}=0.01$

Table 5. Estimates of heritability (on diagonal) and genetic correlations (above diagonal) with standard errors (in brackets) and phenotypic correlations (below diagonal) for live weight, greasy fleece weight and wool quality traits in Finnsheep lambs (Data I).

\begin{tabular}{|c|c|c|c|c|c|c|}
\hline Trait & LW & GFW & $\mathrm{CF}$ & SL & MFD & $\mathrm{FD}_{\mathrm{cv}}$ \\
\hline Live weight (LW) & $0.44(0.04)$ & $0.56(0.07)$ & $0.22(0.07)$ & $-0.01(0.06)$ & $0.28(0.08)$ & $0.21(0.08)$ \\
\hline Greasy fleece weight (GFW) & 0.12 & $0.55(0.07)$ & $-0.14(0.06)$ & $0.35(0.06)$ & $0.69(0.10)$ & $0.64(0.12)$ \\
\hline Crimp frequency $(\mathrm{CF})$ & 0.07 & -0.05 & $0.47(0.03)$ & $-0.75(0.03)$ & $-0.56(0.07)$ & $-0.74(0.07)$ \\
\hline Staple length (SL) & -0.09 & 0.09 & -0.58 & $0.65(0.03)$ & $0.50(0.06)$ & $0.72(0.06)$ \\
\hline Mean fibre diameter (MFD) & 0.32 & 0.14 & -0.26 & 0.53 & $0.62(0.07)$ & $0.54(0.10)$ \\
\hline Fibre diameter variation $\left(\mathrm{FD}_{\mathrm{cv}}\right)$ & -0.02 & 0.09 & -0.45 & 0.20 & 0.69 & $0.54(0.07)$ \\
\hline
\end{tabular}


Puntila, M.-L. et al. Genetic parameters for wool traits in finnsheep lambs

and 0.01 , respectively (Table 6). Notter and Hough (1997) have found similar direct heritabilities for both traits with bivariate analysis, while the genetic correlation between direct effects for $120 \mathrm{~W}$ and GFW were lower in the present study. For $120 \mathrm{~W}$ the estimates of direct heritabilities changed from 0.38 when estimated together with GFW to 0.51 when analysed jointly with $42 \mathrm{~W}$. Also for $42 \mathrm{~W}$ the direct heritability was higher when analysed together with GFW. This can probably be explained by higher genetic correlations between $42 \mathrm{~W}$ and $120 \mathrm{~W}$ than between $120 \mathrm{~W}$ and GFW. Without maternal effects the genetic correlation between $120 \mathrm{~W}$ and $42 \mathrm{~W}$ was 0.88 while with GFW it was 0.41 . The common environment components $\left(\mathrm{c}^{2}\right)$ of $42 \mathrm{~W}$ and $120 \mathrm{~W}$ were 0.04 and 0.05 , respectively. The similar values have been found in other studies (e.g. Näsholm and Danell 1996). The amount of data on fleece weight was not sufficient to estimate $\mathrm{c}^{2}$ for this trait. The maternal heritability of fleece weight was very low which is in agreement with Mortimer and Atkins (1994) and Wuliji et al (2001). Also the components for heritable maternal effect for $42 \mathrm{~W}$ and for $120 \mathrm{~W}$ were very small. In our previous studies (Puntila and Nylander, 1997) we have found $\mathrm{h}^{2}{ }_{\mathrm{m}}=015$, 0.10 and 0.02 for birth weight, $42 \mathrm{~W}$ and $120 \mathrm{~W}$, respectively. This is consistent with the estimates by Tosh and Kemp (1994) for the prolific Romanov sheep and by Olesen et al. (1995) and Wuliji et al. (2001) which have shown that maternal effects are important only for the live weight at younger ages. The correlations for maternal effects are hard to interpret bearing in mind that all the maternal heritabilities were very small.

\section{Conclusions}

This study pointed out for the first time the genetic differences of wool characteristics between the Finnsheep lambs. The coloured lambs had denser fleece, while the white ones had more lustrous and finer wool. Sex, birth/rearing type and lamb age also had an influence on wool traits. The moderate to high heritability estimates and favourable genetic correlations for most of the wool quality traits and fleece weight suggest that the genetic progress through selection on these traits would be relatively easy. There is no antagonistic effect between GFW and LW, so genetic progress can be achieved simultaneously for live weight and fleece weight. Measurements with the OFDA gave verification about the minor occurrence of medullated fibre in the Finnsheep and also more exact information about the fibre thickness.

The wool traits are included in the new data base of the Finnish sheep recording scheme. However, the breeders should participate more actively in the recording to facilitate a breeding programme for improvement of wool traits. The measured traits

Table 6. Estimates of genetic parameters for 42-day weight (42W), 120-day weight (120W) and greasy fleece weight (GFW) from bivariate analysis of data on Finnsheep lambs (Data II).

\begin{tabular}{llllllllllll}
\hline Trait1 & Trait2 & $\mathrm{h}^{2}{ }_{\mathrm{d} 1}$ & $\mathrm{~h}_{\mathrm{d} 2}^{2}$ & $\mathrm{~h}_{\mathrm{m} 1}^{2}$ & $\mathrm{~h}_{\mathrm{m} 2}^{2}$ & $\mathrm{r}_{\mathrm{d} 1 \mathrm{~d} 2}$ & $\mathrm{r}_{\mathrm{d} 1 \mathrm{~m} 1}$ & $\mathrm{r}_{\mathrm{d} 1 \mathrm{~m} 2}$ & $\mathrm{r}_{\mathrm{d} 2 \mathrm{~m} 1}$ & $\mathrm{r}_{\mathrm{d} 2 \mathrm{~m} 2}$ & $\mathrm{r}_{\mathrm{m} 1 \mathrm{~m} 2}$ \\
\hline $42 \mathrm{~W}$ & $\mathrm{GFW}$ & 0.36 & 0.43 & 0.07 & 0.03 & 0.20 & 0.25 & -0.04 & 0.30 & 0.01 & 0.92 \\
120W & GFW & 0.38 & 0.36 & 0.01 & 0.01 & 0.23 & 0.38 & 0.27 & 0.93 & 0.81 & 0.95 \\
$42 \mathrm{~W}$ & $120 \mathrm{~W}$ & 0.41 & 0.51 & 0.06 & 0.04 & 0.85 & 0.17 & -0.20 & 0.25 & -0.26 & 0.85 \\
\hline
\end{tabular}

$\mathrm{h}_{\mathrm{d} 1}^{2}$ and $\mathrm{h}_{\mathrm{d} 2}^{2}=$ direct heritability for traits 1 and 2 ;

$\mathrm{h}_{\mathrm{m} 1}^{2}$ and $\mathrm{h}_{\mathrm{m} 2}^{2}=$ maternal heritability for traits 1 and 2

$r_{\mathrm{d} 1 \mathrm{~d} 2}=$ correlation between direct additive genetic effects of trait 1 and 2

$\mathrm{r}_{\mathrm{d} 1 \mathrm{~m} 1}=$ correlation between direct additive genetic effects of trait 1 and maternal genetic effects of trait 1

$r_{\mathrm{d} 1 \mathrm{~m} 2}=$ correlation between direct effects of trait 1 and maternal genetic effects of trait 2

$r_{\mathrm{d} 2 \mathrm{~m} 1}=$ correlation between direct effects of trait 2 and maternal genetic effects of trait 1

$\mathrm{r}_{\mathrm{d} 2 \mathrm{~m} 2}=$ correlation between direct effects of trait 2 and maternal genetic effects of trait 2

$r_{\mathrm{m} 1 \mathrm{~m} 2}=$ correlation between maternal genetic effects 
Vol. 16 (2007): 124-135

CF and SL could be included in the breeding objective. The number of crimps per the unit of staple length represents fibre fineness and has a high negative genetic correlation with FD and SL. Both traits CF and SL are important for wool processing and yarn quality. The main target should be medium fine wool with the crimp frequency from 6 to 8 per $3 \mathrm{~cm}$ which corresponds to the fineness grade 54 (medium size of curl). To reduce the unevenness of fleece quality often criticised by the spinning mills, fleece uniformity should also be taken into consideration as a selection goal.

There is interest in using wool for innovative products, such as very soft fabrics suitable for underwear or for conditioning items of garment, sometimes called medical wool. Therefore we need information on the wool traits and better knowledge about the possibilities to improve them through selection. The study is giving clear guidelines how the new information can be incorporated in the existing data recording scheme and in the selection programme to improve the wool traits in Finnsheep.

Acknowledgments. This study was partly based on the results of the Fine Finnwool project which was also financed partly by the funds for National Rural Development (regional EU $5 \mathrm{~b}$ programme). Fibre diameter measurements (OFDA) were financed by the European Fine Fibre Network (FAIR3 CT96 1597). We appreciated all the financial support. We would like to thank warmly the partners for the enthusiasm and work during the project and prof. Asko Mäki-Tanila for critical reading of the manuscript. We would like to thank both the referees for very careful and constructive review work.

\section{References}

Atkins, K.D.1986, A genetic analysis of the components of lifetime productivity in Scottish Blackface sheep. Animal Production 43: 405-420.

Bray, A.R., O`Connell, D \& Saville, D.J. 2002. Genes with major effects on wool traits detected in Finn cross sheep. Proceedings of the New Zealand Society of Animal Production 62: 65-68.

Conington, J, \& Murphy, A. 2003. A genetic analysis of wool characteristics and lamb performance traits in Scottish Blackface sheep. Animal Science 77: 355- 362.
Donald, H.P. \& Read, J.L. 1967. The performance of Finnish Landrace sheep in Britain. Animal Production 9: 471- 476.

Eythórsdottir, Emma. 1999. Genetic variation in woolskin quality of Icelandic lambs. Livestock Production Science 57: 113-126.

Fahmy, M.H.1987. The accumulative effect of Finnsheep breeding in crossbreeding schemes: Wool production and fleece characteristics. Canadian Journal of Animal Science 67: 1-11.

Flanagan, S.P.1967. Preliminary observations of Finnish Landrace and Texel fleeces. Agricultural Institute of Republic of Ireland, Animal Production Research Division. Research Report, pp. 79-80. Animal Breeding Abstracts 35: 3078.

Fogarty, N.M.1995. Genetic parameters for live weight, fat and muscle measurements, wool production and reproduction in sheep: a.review. Animal Breeding Abstracts 63: 101-143.

Gjedrem,T.1969. Phenotypic and genetic parameters for fleece weight and some wool quality traits. Acta Agriculturae Scandinavica 19: 103-115.

Gregory, I.P. 1982a. Genetic studies of South Australian Merino sheep. III Heritabilities of various wool and body traits. Australian Journal of Agricultural Research 33: 103-115.

Hanford, K.J., Van Vleck, L.D.\& Snowder, G.D. 2002. Estimates of genetic parameters and genetic change for reproduction, weight, and wool characteristics of Columbia sheep. Journal of Animal Science 80: 3086.3098.

Hanford, K.J., Van Vleck, L.D.\& Snowder, G.J. 2003. Estimation of genetic parameters and genetic change for reproduction, weight, and wool characteristics of Targhee sheep. Journal of Animal Science 81: 630-640.

Hanford, K.J., Van Vleck, L.D.\& Snowder, G.D. 2005. Estimates of genetic parameters and genetic change for reproduction, weight, and wool characteristics of Rambouillet sheep. Small Ruminant Research 57: 175-186.

James, P.J., Ponzoni, R.W., Walkley, J.R.W. \& Whiteley, K.J. 1990. Genetic parameters for wool production and quality traits in South Australian Merinos of the Collinville family group. Australian Journal of Agricultural Research 41: 583-594.

Jensen, J. \& Madsen, P. 1994. DMU: A package for the analysis of multitrait mixed models. Proceedings $5^{\text {th }}$ World Congress on Genetics Applied to Livestock Production, Guelph, Canada. Computing strategies and software 22: 45-46.

Laker, J.1999. Aiming for increased competitiveness of high quality European animal fibres by improving fibre quality. Newsletter of the European Fine Fibre Network Issue 6. December 1999.

Lupton, C.J.\& Pfeiffer, F.A, 1998. Measurement of medullation in wool and mohair using an optical Fibre Diameter Analyser. Journal of Animal Science 76: 1261-1266.

Mortimer, S.I. \& Atkins, K.D. 1994. Direct additive and maternal genetic effects on wool production of Merino sheep. In: Proceedings of the $5^{\text {th }}$ World Congress on Genetics Applied to Livestock Production. Guelph, vol 18, p.103-106.

Neumeier, A. \& Groeneveld, E. 1998. Restricted maximum likelihood estimation of covariances in sparse linear models. Genetics, Selection, Evolution. 30: 3-26. 
Puntila, M.-L. et al. Genetic parameters for wool traits in finnsheep lambs

Notter, R.D.\& Hough, J.D. 1997. Genetic parameter estimates for growth and fleece characteristics in Targhee sheep. Journal of Animal Science 75: 1729-1737.

Näsholm, A.\& Danell, Ö. 1996. Genetic relationships of lambs weight, maternal ability, and mature ewe weight in Swedish finewool sheep. Journal of Animal Science 74: 329-339.

Näsholm, A .2005. Genetic study on pelt quality traits in the Gotland sheep breed. Acta Agriculturae Scand Section A 55: 57-65.

Olesen, I., Swendsen, M., Klemetsdal, G. \& Steine, T.A. 1995. Application of a multiple-trait animal model for genetic evaluation of maternal and lamb traits in Norwegian sheep. Animal Science 60: 457- 469.

Ponzoni, R.W., Rogan, I.M \& James, P.J.1990. Genetic improvement of apparel and carpet wool production. In: Proceedings of the $4^{\text {th }}$ World Congress on Genetics Applied to Livestock Production. Edinburgh, Scotland. XV:149-166.

Puntila, M-L., Mäki-Tanila, A. \& Nylander, A. 1990. Genetic evaluation for a Finnsheep nucleus flock. Proceedings of the $40^{\text {th }}$ Annual Meeting of the EAAP. Toulouse, France. Book of Abstracts. p. 20.

Puntila, M-L. \& Nylander. A. 1996. Development of Finnsheep for multi-utilization. In : Proceedings of the $24^{\text {th }}$ InterNorden Sheep Meeting. Denmark.p. 73-87.

Puntila, M-L. \& Nylander. A. 1997. Multi-line selection in a Finnsheep nucleus. In : Proceedings of the $48^{\text {th }}$ Annual Meeting of the EAAP. Vienna, Austria. Book of Abstracts. p.23.

Puntila, M-L. 2000. Possibilities to improve wool quality through breeding. The Nordic Fibre meeting. Borås, Sweden. The Nordic Textile Journal, Special edition: Nordic Fibre Meeting p. 43-50.

Qi, K., Lupton, J., Pfeiffer, F.A. \& Minikhiem, D.L. 1994. Journal of Animal Science 72: 1675-1679.

Ryder, M.L.\& Wilson, D.T. 1972. Fleece characteristics and postnatal development in Finnish Landrace $\mathrm{x}$ Merino sheep. Animal Production 15: 75-84.

SAS, 1999-2000. SAS/Proc GLM User's guide Version 8. SAS Institute Inc., Cary, NC, USA.

Safari, E., Fogarty, N.M.\& Gilmour, A.R. 2005. A review of genetic parameter estimates for wool, growth, meat and reproduction traits in sheep. Livestock Production Science 92: 271-289.

Safari, E., Fogarty, N.M., Gilmour, A.R., Atkins, K.D., Mor- timer, S.I., Swan, A.A., Brien, F.D., Greef, J.C. \& van der Werf, J.H.J. 2007. Genetic correlations among

and between wool, growth and reproduction traits in Merino sheep. Journal of Animal Breeding and Genetics124: 65-72.

Souchet, C. 1997. European Fine Fibre Network. Fine wool programme Workshop.I. Villaviciosa, Spain.Report No 1.

Sumner, R.M.W.\& Bigham, M.L. 1993. Biology of fibre growth and possible genetic and non-genetic means of influencing fibre growth in sheep and goats - a review. Livestock Production Science 33: 1-29.

Terho, T. \& Vainikainen, V. 1938. On the characteristics of the Finnish sheep wool (in Finnish). Valtion Maataloustieteellisiä julkaisuja 102 , p 56.

Tosh, J. J.\& Kemp, R.A. 1994. Estimation of variance for lamb weights in three sheep populations. Journal of Animal Science 72: 1184- 1190.

Vainikainen, V. 1946. Crossbreeding Finnish sheep with Schwartzkopf rams (in Finnish). Maataloustieteellinen aikakauskirja 18: 50-62.

Vainikainen, V.\& Hakola, R.1952. Referat : Über die wolle des Finnischen Schafes und die äusseren vorbedingungen ihrer Erzeugung. Maataloustieteellinen Aikakauskirja 24: 162-164.

Wuliji, T., Dodds, K.G., Land, J.T.J., Anrews, R.N \& Turner, P.R. 1999. Response to selection for ultrafine Merino sheep in New Zealand. I. Wool production and wool characteristics of ultrafine fibre diameter selected and control Merino yearlings. Livestock Production Science 58: 33- 44.

Wuliji, T., Dodds, K.G., Land, J.T.J., Andrews, R.N. \& Turner, P.R. 2001. Selection for ultrafine Merino sheep in New Zealand: heritability, phenotypic and genetic correlations of live weight, fleece weight and wool characteristics in yearlings. Animal Science 72: 241-250.

Young, S.S.Y., Brown, G.H., Turner, H.N. \& Dolling, C.H.S. 1965. Genetic and phenotypic parameters for body weight and greasy fleece weight at weaning in Australian Merino sheep. Australian Journal of Agricultural Research 16: 997- 1009.

Yazdi, M.H., Engstöm, G., Näsholm, A., Johansson, K., Jorjani, H.\& Liljedahl, L-E. 1997. Genetic parameters for lamb weight at different ages and wool production in Baluchi sheep. Animal Science 65: 247-255. 
Vol. 16 (2007): 124-135

\title{
SELOSTUS
}

\section{Villan ominaisuuksien geneettinen vaihtelu suomenlammaskaritsoilla}

\author{
Marja-Leena Puntila, Katariina Mäki, Anne Nylander ja Onerva Rintala \\ MTT Biotekniikka- ja elintarviketutkimus ja Helsingin yliopisto
}

Tutkimus sai alkunsa Fine Finnwool -hankkeesta, joka toteutettiin varsinaissuomalaisten ja saariston lampureiden sekä Lounais-Suomen käsi- ja taideteollisuusoppilaitoksen yhteistyönä. Tarkoitus oli luoda villalle lisäarvoa, jotta lammastalouden tuottavuus paranisi. Hankkeessa myös etsittiin keinoja tehostaa koko villaketjua ja kehittää raaka-aineesta valmiita tuotteita. Tutkimuksessa pyrittiin kartoittamaan villan laatuominaisuudet sekä määrittämään mittauskriteeristö niiden arviointia varten. Lisäksi analysoitiin geneettistä vaihtelua. Tutkimus tehtiin kahdesta aineistosta. Pääaineisto käsitti kolmivuotisen Fine Finnwool -projektin villa-arvostelun tulokset, joihin yhdistettiin vastaavat tiedot Pelson suomenlampaan ydinkatraasta ja Lihasulan säätiön katraasta. Villan laatu arvosteltiin kaikkiaan 5309 karitsalta, joiden joukossa oli sekä valkoisia että värillisiä eläimiä. Tutkittavat ominaisuudet olivat: hienousluokka, kiharakaarien lukumäärä $3 \mathrm{~cm}: n$ matkalla, tiheys, villapeitteen tasaisuus, kiilto sekä tapulin muodostus ja pituus. MTT:n osallistuminen Euroopan hienokuituja käsittelevän verkostohankkeen hienovillaryhmään mahdollisti villanäytteiden optisen analysoinnin OFDA-menetelmällä kuidun hienouden arvioimiseksi. Toinen havaintoaineisto perustui Pelson ydinkatraassa suoritettuihin villan määrän ja muutamien laatuominaisuuksien arvioimiseen sekä villapainojen ja kasvuominaisuuksien maternaalisten vaikutusten tarkasteluun. Tutkimuksen mukaan valkoisten karitsojen villapeite oli yhdenmukaisempi, villa hienompaa ja kiiltävämpää ja tapulit selväpiirteisempiä kuin värillisillä. Värillisten karitsoiden villa puolestaan oli tiheämpää. Kuitumäärityksillä saatiin mielenkiintoista tietoa suomenlammaskaritsoiden villan hienoudesta. Laboratoriomääritykset vahvistivat, että suomenlampaalla esiintyy ydinvillaisuutta erittäin vähän. Villan mitattavat laatuominaisuudet osoittautuivat hyvin periytyviksi ja silmämääräisesti arvioitavat kohtalaisesti periytyviksi. Villan ominaisuuksissa on runsaasti perinnöllistä vaihtelua, joten mahdollisuudet parantaa ominaisuuksia valinnan avulla ovat hyvät. Villatuotoksen ja kasvupotentiaalin kehittäminen eivät ole ristiriidassa keskenään. Jotta villaominaisuudet saataisiin suomenlampaiden jalostusohjelmaan, villan taloudellista arvoa on kuitenkin nostettava. 